Ida Katrine Riksaasen Hatlevik ${ }^{*}$

* Department of Teacher Education and School Research, Faculty of Educational Sciences, University of Oslo, at Pb 1099, Blindern, 0317 OSLO, Norway.

E-mail address: i.k.r.hatlevik@ils.uio.no

Telephone number: 004798005256

\title{
The impact of prospective teachers' perceived competence on subsequent perceptions as schoolteachers
}

\begin{abstract}
:
This longitudinal study examines connections between 110 teachers' perceived professional competence acquired during professional preparation and later perceptions as schoolteachers in Norway. The results indicate that theoretical understanding plays an important role in schoolteachers' professional competence development and that prospective and practising schoolteachers do not tend to perceive themselves as either good theorists or good practitioners. Furthermore, the results contradict research arguing that the teacher education programme has limited effect. Instead, the results indicate that the level of perceived competence acquired during professional preparation in the general teacher-training programme is of major importance for perceived mastery of teaching as a schoolteacher. In addition, the results also underscores the importance of experiencing continuing mastery of teaching requirements for supporting perceptions of teaching specific self-efficacy over time. This finding again supports previous research that has emphasised the importance of supporting teaching specific self-efficacy during both the period of teacher education of prospective teachers and the induction period of newly qualified teachers.
\end{abstract}

Keywords: self-efficacy; competence; longitudinal; structural equation modelling; teacherefficacy; teacher education. 


\section{Introduction}

Schoolteachers' perceived competence is an important explanatory factor in a variety of areas. Previous research has identified teachers' perception of their own competence as a schoolteacher as an important predictor for pupils' motivation and achievements (Caprara, Barbaranelli, Steca, \& Malone, 2006; Guo et al., 2012), teachers' professional identity (Canrinus, Helms-Lorenz, Beijaard \& Hofman, 2012), job satisfaction (Caprara et al., 2006), professional commitment (Skaalvik \& Skaalvik, 2007; Ware \& Kitsantas, 2007) and attrition from the teaching profession (Hong, 2012; Klassen \& Chiu, 2011). The development of schoolteachers' perceived competence is therefore an important subject to investigate. However, few studies have examined the longitudinal effect of individuals' perceived competence as prospective teachers on their later perceptions as schoolteachers (Hoy \& Spero, 2005). This study investigates teachers' perception of some aspects of their professional competence at three points of measurement. First measuring point is when they are prospective teachers (i.e. as teacher students near the end of their teacher education programme), second, as newly qualified, and third, as experienced teachers.

Many newly qualified teachers experience a gap between competence acquired during general teacher education and competence demands in professional practice as schoolteachers (Smeby \& Mausethagen, 2011). The shift from prospective teacher to professional schoolteacher has been characterised as a reality shock (McCormack \& Thomas, 2003), a cultural shock (Wideen, Mayer-Smith, \& Moon, 1998) and a praxis shock (Gold, 1996). These experiences are assumed to be negatively related to perceived mastery of teaching (Caspersen \& Raaen, 2014) and, thereby, to the experience of possessing an adequate level of relevant professional competence. However, the results of Caspersen and Raaen's (2014) study indicate that a supportive culture in the workplace has a greater influence on how individual teachers cope with their work than the amount of experience gained. Taken 
together, these research findings suggest that perceived professional competence as students in the general teacher-training programme plays a minor role in perceived professional competence as schoolteachers and that workplace learning could compensate for insufficiencies in competence that appear in general teacher education. However, research on the longitudinal aspects of the relationship between prospective teachers' learning in general teacher education and later as newly qualified schoolteachers is sparse (Richter, Kunter, Klusmann, Lüdtke, \& Baumert, 2011). In addition, Joram's (2007) research on the beliefs of aspiring teachers, practising schoolteachers and professors about what counts as legitimate knowledge in education indicates that whereas education professors consider research-based findings and general principles of teaching to be important for their education students to learn, many prospective and practising schoolteachers discount the validity of such material (p. 133). Previous studies, however, in nursing (Bonis, 2009; Evans \& Donnelly, 2006) and psychotherapy (Orlinsky \& Rønnestad, 2005) have pointed to a reciprocal relationship between academic theoretical knowledge and practical competence. However, few studies have investigated this relationship for prospective and practising schoolteachers.

To better understand the dynamics and development of teachers' perception of professional competence, it would thus be of interest to investigate the connections amongst perceived theoretical understanding, teaching skills and professional confidence and to examine how perceptions of professional competence as prospective teachers influence subsequent perceptions as newly qualified teachers and later as more experienced ones. Is theoretical understanding needed for professional confidence and teaching skills? Does perceived competence as a prospective teacher have an impact on subsequent perceptions as a schoolteacher? The answers to these two questions will shed light on both the importance of theoretical knowledge for professional practice and the effect of competence acquired during 
professional preparation in the general teacher-training programme on subsequent mastery of teaching as a schoolteacher.

\section{Theoretical framework}

Teachers' perceptions of their theoretical understanding, confidence in their role as a schoolteacher and mastery of the teaching task are put forward here as important aspects of perceived professional competence. Thus, it is important to understand how teachers' perceptions of these aspects are related to each other over time. In the teaching literature there exist a huge body of research on the constitution of teacher competence and the knowledgebase of teaching. Furthermore, teachers' beliefs and perception of own mastery of the teaching task (teacher efficacy), have been thoroughly investigated in relation to influential contextual factors and outcome results. However, few studies have focused on both the interrelationships and the longitudinal relationship between teachers' perceptions of their theoretical understanding, confidence in the role as a teacher and mastery of the teaching task. From the literature review referred to below on teacher-efficacy, teachers' beliefs, teacher specific and professional knowledge, competence and competence development, I derived hypotheses regarding the relationships between the indicators of perceived professional competence among prospective, newly educated and experienced teachers. In the following two sections, I elaborate upon the studies used to formulate the hypotheses that are been tested in this article.

\section{A reciprocal relationship between different aspects of professional competence}

Professional practice presupposes an interplay between different kinds of knowledge, skills, attitudes and judgement (Sullivan \& Rosin, 2008). In the literature about teacher knowledge and competence, various aspects of propositional knowledge (Shulman, 1987), personal 
knowledge (Day \& Sachs, 2004), societal issues (Ben-Peretz, 2011) contextual knowledge, as well as practical knowledge and skills have been emphasised (Cochran-Smith \& Lytle, 1999; Verloop, Van Driel and Meijer, 2001). In short, prospective teachers need to learn not only what and how to teach, but also how to reflect upon why-related questions linked to educational goals, content, methods of teaching and learning and the school's role in society (Carr, 1993; Shulman, 1987; Winch, 2014). Thus, measuring teachers' knowledge and competence is a complex task, involving, for example, measuring subject knowledge, didactical knowledge, pedagogical knowledge, teaching skills, classroom management skills, relational competence, attitudes, ethical reflective skills, ability to engage and motivate pupils to participate in the learning activities and the possession of a diverse methodological repertoire to draw upon when planning and carrying out the teaching task. The present study, however, does not measure all these aspects of teaching competence. Instead the study focuses on the interrelationship between perceptions of theoretical knowledge, practical teaching skills and professional confidence. Research has identified a close connection between teachers' beliefs about education, teaching, and learning and their teaching practice (Fang, 1996; Pajares, 1992; Waters-Adams, 2006). However, few studies have investigated the relationship between teachers' beliefs about own theoretical understanding and their perception of mastering of the teaching task.

The present study is inspired by research on professional competence development in other professions that has uncovered a potential fruitful relationship between different aspects of professional competence and experience. Evans and Donnelly (2006) identified a non-static relationship between different aspects (i.e. theoretical knowledge, judgement and practical skills) of professional competence for nurses. Orlinsky and Rønnestad (2005) found that the possession of multiple theoretical perspectives to draw upon whilst reflecting on practice positively influences psychotherapists' professional work experience. Transferred to 
schoolteachers, these results suggest a close relationship between possessing an adequate level of theoretical understanding, which is both subject related and pedagogical, and practical skills, which include being confident in how to teach, how to motivate students and how to manage a class. Furthermore, they suggest that the various aspects of perceived professional competence are viewed as mutually reinforcing and, therefore, might be expected to be closely related (hypothesis 1). However, as previously mentioned, contextual factors of the work environment and interpersonal characteristics of individual teachers (Ben-Peretz, 2011), may play important roles in teachers' perception of professional competence; however, they are not investigated empirically in this study.

\section{Teacher-efficacy}

Previous studies indicate that formal teaching competence alone is not a sufficient factor for good teaching practice and student learning as other individual and contextual factors are also influential (Gustafsson, 2003; Hattie, 2008). Then again, some individual competences seem to be more vital than others for good teaching practice; in particular, 'teacher efficacy' (i.e. self-efficacy in teaching) is considered a key issue (Bandura, 1997; Skaalvik \& Skaalvik, 2007). A large and growing body of research have revealed the positive effects of teachers' teaching specific self-efficacy beliefs on teachers' motivation, teaching and student outcomes (Tschannen-Moran \& Johnson, 2011).

Bandura's (1997) social cognitive theory points to a potential positive effect of individuals' perception of their own competence and capabilities in a specific area of interest (i.e. self-efficacy) for continual growth and feeling of mastery in that same field and similar fields of interest. Bandura stated that self-efficacy in a specific area affects individuals' thought processes, levels of persistence, degrees of motivation and affective states regarding tasks within the same area, thereby influencing individuals' performance. Enhancing 
individuals' self-efficacy beliefs in a specific set of tasks increases their performance levels on those tasks; however, those same individuals may fail in tasks that exceed their perceived coping capabilities (Bandura). For the teaching profession, "a teacher's efficacy belief is a judgement of his or her capabilities to bring about desired outcomes of student engagement and learning, even among those students who may be difficult or unmotivated" (TschannenMoran \& Hoy, 2001, p. 783). In other words, teacher efficacy is about 'teachers' beliefs that they are capable of carrying out good teaching in the classroom' (Christophersen et al., 2015, p. 2), and is identical to individuals' perception of their teaching skills, which implies overall perceived mastery of the teaching task and confidence in their role as a teacher. Bandura claimed that these beliefs were more powerful than one's actual abilities, thus self-efficacy beliefs can become self-fulfilling prophesies. In relation to occupational socialisation, Bandura put forth the following argument:

The sense of efficacy that newcomers bring and further develop during the course of their occupational training at the beginning stage of their careers contributes to the success of this socialization process. Newcomers who come with a secure sense of efficacy learn more and perform better during the period of training than do their low self-efficacy counterparts. (p. 446)

A reasonable assumption to draw from Bandura's (1997) theory is that newly qualified teachers' perceptions of mastery of the teaching task and confidence in their role as teachers positively influence later perceptions as more experienced teachers.

This study focuses on perceived professional competence, which is a broader concept than the concept teacher-efficacy. In addition, as previously mentioned, teachers' perceived theoretical understanding is an essential aspect of teachers' perceived professional competence. This notion is in line with Young's (2008) emphasis on the importance of theoretical knowledge for improving professional practice. Young (2008) stressed that 
theoretical knowledge has an explanatory power and a capacity for generalisation, which are essential in providing a reliable basis for moving beyond and being able to reflect upon particular forms of practices to improve individuals' teaching practice.

Based on Bandura's (1997) theory of self-efficacy and Youngs' (2008) emphasis on the importance of theoretical knowledge, it is considered essential to view professional teacher competence as a combination of mastery of teaching, confidence in the role as a teacher and theoretical understanding. In line with Bandura's theory of self-efficacy, it is reasonable to assume that prospective teachers' perceived professional competence affects later perceptions of their professional competence as newly qualified teachers (hypothesis 2) and as more experienced teachers (hypothesis 3). Likewise, perceived professional competence as newly qualified teachers affects their perceptions of their competence as more experienced teachers (hypothesis 4).

According to Bandura (1997) there are four major influences on self-efficacy beliefs vicarious experiences, verbal persuasion, physiological arousal, and mastery experiences. Previous research has identified mastery experiences as the most powerful influence when it comes to enhance prospective teachers' and newly qualified schoolteachers' professional selfefficacy beliefs (Tschannan-Moran \& Johnson, 2011). Research has also shown that novice teachers' professional self-efficacy is positively affected by interpersonal support and (Tschannen-Moran \& Hoy, 2007), collective work, cooperation and exchanges amongst teachers (Grangeat \& Gray, 2008), and negatively affected by problem behaviour in the classroom (Christophersen et al., 2015). In line with these results, it is reasonable to expect that the impact of prospective teachers' confidence and anticipation of their own professional competence on later perceptions as more experienced teachers is to some extent dependent on their work experience and the presence of appropriate support as newly qualified teachers. This implies that newly qualified teachers' perceived professional competence acts as a 
mediator between the perceived competence of prospective teachers on the one hand and that of experienced schoolteachers on the other hand (hypothesis 5).

\section{Aims of the study}

The main aims of the present study are to examine the relationship between schoolteachers' own beliefs of possessing a sufficient amount of professional competence at three measurement points and to investigate if a potential mutual interdependency exists between the perceived competence as prospective teachers and newly qualified teachers and later perception as more experienced teachers (see Figure 1). Another area of interest is the potential existence of links between different aspects of perceived professional competence (e.g. theoretical understanding, mastery of the methods involved in practising teaching and confidence in the professional role as a schoolteacher). The following five hypotheses are formulated:

Hypothesis 1: Perceived theoretical understanding, confidence in the role as a schoolteacher and mastery of the methods involved in practising teaching are expected to correlate.

Hypothesis 2: Anticipated professional competence as prospective teachers positively influences perceived professional competence as newly qualified schoolteachers.

Hypothesis 3: Anticipated professional competence as prospective teachers positively influences perceived professional competence as experienced schoolteachers.

Hypothesis 4: Perceived professional competence as newly qualified schoolteachers positively influences perceived professional competence as experienced schoolteachers.

Hypothesis 5: Perceived professional competence as newly qualified schoolteachers acts as a mediator between anticipated professional competence as prospective teachers on the one hand and experienced schoolteachers on the other hand. 


\section{Methodology}

This is a longitudinal study with three points of measurement (2003, 2006 and 2009). The hypotheses were tested using structural equation modelling (SEM). The model tested is a fully latent model; the model examines the relationships amongst three latent variables: anticipated professional competence as prospective teachers, perceived professional competence as newly qualified schoolteachers and perceived professional competence as experienced schoolteachers. This type of SEM allows tests of hypotheses concerning patterns of causal effects, and, at the same time, it can incorporate a measurement model that represents observed variables as indicators of underlying factors (Kline, 2005). The hypotheses were tested using a model-generating application of SEM, which is a blend of confirmatory and exploratory analyses (Kline). The hypothesised model (model 1) underwent testing (confirmatory analysis), and when one of the regression paths in the initial model was insignificant, it was removed, and the model was modified (exploratory analysis). The altered model (model 2) was then tested with the same data. The goal of the procedure was to develop a theoretical model with statistical correspondence to the data (Kline, p. 11).

\section{Sample}

The data used in this study were derived from StudData, a database for Studies of Recruitment and Qualification in the Professions in Norway; the data were obtained and handled by the Centre for the Study of Professions at Oslo and Akershus University College of Applied Sciences. This is a longitudinal survey of students in professional programmes and professionals across a range of professions.

This study invited 467 prospective teachers in 4-year concurrent programmes qualifying for work in grades 1 through 10 to participate. This general teacher education 
programme (240 European Credit Transfer and Accumulation System [ECTS] credits) includes 20 to 22 weeks of external placement in primary and lower secondary schools. Until recently, the induction of newly qualified teachers in Norway had been diverse and dependent on the school principal. As of 2010, newly qualified teachers are offered supervision and mentorship during their first year as schoolteachers. This is a voluntary arrangement, however, and the respondents in this study were educated before this arrangement was systematically offered to all newly qualified teachers. Surveys were conducted at three different points in time: (1) in 2003, when the prospective teachers were at the end of either the third or fourth year of their teacher education programme; (2) in 2006, when the respondents had spent, respectively, 2 or 3 years as schoolteachers; and (3) in 2009, when the respondents had spent, respectively, 5 or 6 years as schoolteachers. Day, Sammons, Stobart, Kington, and Gu (2007) identified six professional life phases for teachers (0-3, 4-7, 8-15, 16-23, 24-30 and 31+ years of teaching). This study concerns the first two phases and the prospective teacher phase. I have chosen to label the different measurement levels as prospective, newly qualified and experienced so as to discriminate amongst them more easily - even though it might be argued that at both the prospective and newly qualified levels, the respondents could be described as novice teachers. The third level is labelled 'experienced teachers' to denote that these respondents have reached the most experienced level that is measured in this study; this stage might be labelled differently in other studies.

In total, 110 schoolteachers, educated at three different university colleges in Norway, answered the questionnaire at all three measurement points. The response rates were $76 \%$ at the prospective teacher level, $34 \%$ at the newly qualified schoolteacher level and $24 \%$ at the experienced teacher level. In this study, only those respondents who answered the questionnaire at all three measurement points were included, which means that the analysed sample comprised only $24 \%$ of the target population. A low response rate could be 
problematic and could lead to biased results if 'the nonresponse is nonrandom, and if it is in some way correlated with the variables measured in the survey' (Hox \& De Leeuw, 1994, p. 330). In this study, no significant differences were detected between the mean values and correlation coefficients of the restricted (i.e. respondents who answered the survey at all three measurement points) and original samples (i.e. all the survey responses), as well as with the mean values and correlation coefficients of the respondents from the original samples who were not included in the restricted sample at the prospective teacher measurement point. In addition, the analysis revealed similar values for standard deviation, skewness and kurtosis for the different samples. Furthermore, age and gender in the different samples were compared. No significant differences in mean age in 2003 (i.e. prospective teacher level) were detected amongst the restricted sample (27.1 years), the original sample (26.5 years) and those from the original sample who were not included in this study (26.2 years). However, a significant difference was found in the distribution of gender between the different groups; the restricted sample consisted of $81 \%$ women, whereas the original sample consisted of $73 \%$ women. No significant differences existed in the mean values and correlation coefficients between men and women at the newly qualified level. A comparison of the different samples should therefore indicate that the restricted sample is sufficiently representative of the original sample.

\section{Measurement of professional competence}

The items used in this study are part of a longitudinal survey developed by researchers of professional studies to map prospective teachers' evaluations of their professional training during their initial education at several university colleges and their later professional performance. The concept of professional competence consists of both relevant theoretical knowledge and practical teaching skills. The items used in this study represent central parts of 
these different aspects and are inspired by Orlinsky and Rønnestad's (2005) research involving psychotherapists, especially their questionnaire 'The Development of Psychotherapists Common Core Questionnaire' - although slightly modified to suit the teaching profession - which should indicate sufficient content validity. However, professional competence is a complex matter, and it can be argued that it cannot be sufficient measured with just a few items, like in this study. Nevertheless, Gogol et al. (2014) found that the correlational patterns between single item measures and an external criteria was similar to those obtained with long scales, which indicate that single item measures may represent psychometrically sound alternatives when long scales are not available. Professional competence was measured with two or three items at each level. Two of the items were present at every measurement level, namely, 'How confident do you feel in your role as a schoolteacher?' and 'How good is your theoretical understanding?' In addition, at the newly qualified and more experienced levels, the participants were asked the following question: 'How well have you mastered the methods involved in practising teaching?' Valuation of theoretical understanding maps to some extent the participants' perception of the amount of profession-relevant codified knowledge they possess. Because theoretical understanding was measured with only one item, this study does not discriminate amongst different forms of theoretical understanding (i.e. subject-content, didactic and pedagogical theories). Both confidence in the professional role as a schoolteacher and the mastery of the methods involved in practising teaching to some degree map the participants' perceptions of their practical teaching skills. However, this study does not cover all aspects that might play important roles in professional competence development, such as familiarity with and knowledge about the teaching culture and school environment. Ideally it would have been preferable to measure competence with several items that could capture a wider range of aspects of professional competence. This study, however, is limited by the fact that it is a 
secondary analysis of already collected data. Thus, it would be of interest for further study to investigate the relationship between more aspects of teacher competence.

Owing to the differences between the latent variables in the number of observed variables measured, the latent variables measuring professional competence were referred to as anticipated professional competence at the prospective teacher level and as perceived professional competence at the newly qualified and experienced teacher levels. It can also be argued that at the prospective teacher level, a kind of anticipation about the future development of their own professional competence and the degree of confidence in their own competence prior to practising as a schoolteacher are measured, whereas at the newly qualified and experienced teacher levels, a more genuine perceived professional competence is measured. The items were measured on a Likert-type scale ranging from 1 (absolutely not) to 6 (to a large degree) at the prospective and experienced levels and from 1 (not at all) to 5 (to a very large degree) at the newly qualified level.

The non-static interrelationship involving the different aspects of professional competence accounted for in the Theoretical framework implies that professional competence requires the presence of both practical teaching skills and theoretical understanding. This is an argument for combining the different aspects into a factor that represents what the different measured variables have in common, instead of dealing with them separately or simply adding them together in an index. The factor loadings of each latent variable were relatively high $($ range $=.57-.81)$, indicating sufficient convergent validity (see Table 2). Cronbach's alpha reliability coefficients were .65 for perceived professional competence at the prospective level, .76 at the newly qualified level and .74 at the experienced level, which are considered adequate (Kline, 2005, p. 59). The inter-item correlation was in the recommended range or above Briggs and Cheek's (1986) recommendation of an optimal range of .2 to .4. The inter-item correlation for professional competence was .38 at the prospective level, 
ranged from .45 to .58 at the newly qualified level and ranged from .44 to .66 at the experienced level, indicating internal consistency in the latent variables. The correlations between the observed variables were relatively high (see Table 1), and the correlations between the latent variables were high (see Table 3), which indicates the strong predictive value of the concept as measured at a certain level on succeeding levels.

\section{Data analysis}

The data were analysed using Statistical Product and Service Solutions (SPSS) software and Mplus software. Univariate normality was evaluated by checking the marginal distribution of each variable. Table 1 shows that the univariate distribution is in the range of normality (between -1 and 1 for both skewness and kurtosis) for all but one of the observed variables. The kurtosis of this item (2.4), however, is not excessive enough to threaten the maximum likelihood estimation. The missing data in this study are missing completely at random (MCAR) (SPSS Little's MCAR test: chi-square $=29.163, d f=28, p=.404)$. In Mplus, the full information maximum likelihood estimation was used to deal with missing data. Table 1 shows the input data for the SEM analysis. In the following analysis, the goodness-of-fit indices (the comparative fit index [CFI], the root mean square error of approximation [RMSEA] and standardised root mean square residual [SRMR]) are reported in addition to the chi-square test. A model data fit is considered good if $\mathrm{CFI} \geq .95, \mathrm{RMSEA} \leq .06$ and $\mathrm{SRMR}<$ .08 (Hu \& Bentler, 1999).

\section{Findings}

For all the observed variables at each measurement level, the mean values are at the upper end of the scale, indicating that, on average, the respondents stated that they to some extent, but not entirely, are confident in their role as a schoolteacher, that their theoretical understanding 
is good and that they have mastered the methods involved in practising teaching relatively well.

As shown in Table 1, statistically significant correlations exist between almost every observed variable, indicating a close relationship between perceptions of theoretical understanding, confidence in their role as a schoolteacher and mastery of the teaching task. Table 3 shows that there are significant correlations between all the latent variables (ranging from .64 to .81). In addition to correlations, another necessary condition for establishing causal relationship is to know which event occurs first. This is a longitudinal study, with three years apart between every measurement level. Therefore, with certainty, one can know which phenomena occurs before the next one. In addition, Little (1991) argue that in order to talk about causal relationships in social science one have to be able to give a plausible theoretical explanations on the individual level for why one event affects another. Bandura's social cognitive theory, presented in the Theoretical framework, points at potential positive effect of individuals' perception of their own competence on subsequent perceptions of competence. Consequently, based on the hypothesised model, it is interesting to examine how anticipated professional competence as a prospective teacher affects perceived professional competence later on, as both newly qualified and more experienced schoolteachers. The SEM analysis of model 1 , however, reveals that one of the estimates is not statistically significant. Alternative models were tested, and only when removing the latent variable 'perceived professional competence as a newly qualified schoolteacher' did the regression between anticipated professional competence at the prospective level and perceived professional competence at the experienced level become statistically significant. This result indicates that the effect of anticipated professional competence as a prospective teacher is fully mediated through perceived professional competence measured at the newly qualified level. Mediating relationships occur when a third variable plays an important role in governing the relationship 
between the other two variables. Being fully mediated in this analysis means that anticipated professional competence at the prospective level influence perceived professional competence measured at the newly qualified level, which in turn influences perceived professional competence at the experienced level.

In model 2 (see Tables 2 and 4 and Figure 2), the regression from anticipated professional competence at the prospective teacher level on the perceived professional competence at the experienced level is removed, and all the estimates are statistically significant and have good fit indices. The explained variance in model 2 is $52 \%$ for the variable 'perceived professional competence as a newly qualified schoolteacher' and $67 \%$ for the variable 'perceived professional competence as an experienced schoolteacher'. Explained variance means what can be attributed to a specific condition (explained). The explained variances in this analysis is high, which indicate that for instance the anticipated professional competence at the prospective teacher level has a strong effect on subsequent perseptions of professional competence.

The results reveal that anticipated professional competence as a prospective teacher is a strong predictor for later perceptions of professional competence. In addition, the effect of anticipated professional competence as a prospective teacher on perceived professional competence as an experienced schoolteacher is fully mediated through the perceived competence as a newly qualified schoolteacher. A change of 1 full standard deviation $(S D)$ unit in anticipated professional competence as a prospective teacher predicts a change of 0.73 $S D$ units as a newly qualified schoolteacher and a change of $0.60 S D$ units as an experienced schoolteacher. A change of 1 full $S D$ unit in perceived professional competence as a newly qualified schoolteacher predicts a change of $0.82 S D$ units as an experienced schoolteacher. In other words, when anticipated professional competence as a prospective teacher increases, the 
analyses predicts a substantial increase in subsequent perceived professional competence as both a newly educated and as an experienced schoolteacher.

\section{Discussion}

The correlation analysis of the observed variables indicates that perceived confidence in the role as a schoolteacher, theoretical understanding and mastery of the methods involved in practising teaching are closely linked together at each measurement point, thus corroborating hypothesis 1 , indicating that theoretical knowledge is important for teacher efficacy. In addition, the correlation analysis suggests that the different aspects of professional competence are closely linked across time, which points to the existence of a reciprocal relationship for schoolteachers involving perceived theoretical understanding, teaching skills and confidence in being a teacher. A similar close relationship involving different aspects of professional competence has also been identified for other professionals (Evans \& Donnelly, 2006; Orlinsky \& Rønnestad, 2005). The results indicate that acquiring theoretical knowledge is positively related to teacher efficacy, which empirically support Young's (2008) notion about theoretical knowledge as essential in providing a reliable basis for moving beyond and being able to reflect upon particular forms of practices to improve individuals' teaching practice. The findings suggest that prospective and practicing schoolteachers do not consider themselves as either good theorists or good practitioners. Moreover, the findings support a mutual interdependence between different aspects of professional competence. The results disprove any potential claims that theoretical knowledge are of limited value in preparing for professional practice. Instead, the findings indicate that theoretical knowledge is essential for competence development. However, this study are limited by using only a small numbers of items. The items used in this study do not discriminate between different forms of theoretical knowledge (i.e. subject knowledge, pedagogical knowledge and didactical knowledge), and 
the study does not contain information about reflective skills and various other aspects of professional competence. It would thus be of interest to investigate further the relationship between different forms of theoretical knowledge, reflective skills, confidence in the role as a schoolteacher and perceived mastery of the methods involved in practising teaching.

The correlations between the latent variables (see Table 3) and the longitudinal SEM analysis of the relationship involving perceptions of professional competence over time (see Figure 2) corroborate the assumption that the confidence in and anticipation of one's own professional competence as a prospective teacher has an effect on subsequent perceived professional competence as a newly qualified schoolteacher (hypothesis 2). The present study thus upholds the notion that it is important to support individuals in their belief in their own professional competence and teaching ability. Bandura (1997) maintained that support and feedback on mastery performance are likely to enhance an individual's aspirations, motivation and persistence in engaging in further professional development. Bandura pointed out that individuals who receive feedback that persuades them that they have the capabilities to succeed are likely to make more effective use of the skills that they have learned.

Both the correlations between the latent variables (see Table 3) and the results of the SEM analysis (see Figure 2) indicate that perceived professional competence as a newly qualified schoolteacher has a substantial effect on perceived professional competence as a more experienced schoolteacher (see Table 4), thus confirming hypothesis 4 . These results point to the importance of appropriate support for newly qualified teachers. Tschannen-Moran and Hoy (2007) have found that novice teachers' professional self-efficacy is affected by interpersonal support.

The correlations between the latent variables indicate that anticipated professional competence at the prospective level has a substantial effect on the experienced level (see Table 3), thus supporting hypothesis 3 . The finding show that the teacher education 
programme can provide a valuable basis for further competence development in the workplace. The effect of anticipated professional competence as a prospective teacher on professional competence as an experienced schoolteacher, however, is completely mediated through perceived professional competence as a newly qualified schoolteacher, thus confirming hypothesis 5 (see Figure 2). In other words, even though a relatively high level of anticipated professional competence measured at the prospective level is a strong predictor for perceiving high professional competence as a more experienced schoolteacher (measured 6 years later), it only has this positive effect as long as professional competence is also perceived as high at the newly qualified schoolteacher level. This indicate that even though previous anticipation of competence as prospective teachers has an impact on their later perceptions as more experienced teachers, it only has this impact as long as the schoolteachers continue to experience mastery of teaching requirements. Taken into account that previous research indicate that problem behaviour in the classroom negatively affects teacher efficacy, while support positively influence teacher efficacy (Christophersen et al., 2015), this finding again substantiates both the notion about the importance of supporting newly qualified teachers (Caspersen \& Raaen, 2014; Grangeat \& Gray, 2008; Tschannen-Moran \& Hoy, 2007) and the idea that perceptions of their own professional competence as prospective teachers influences their aspirations, motivation and persistence for further development (Bandura, 1997). In addition, it might indicate that professional competence acquired at the prospective level plays an important part in how newly qualified teachers are able to reflect upon their teaching practice and, thereby, how they are able to make use of opportunities for support, to engage in reflective discussions and to cooperate with colleagues (Johnston, 1994; Young, 2008). 


\section{Conclusion}

Previous research indicate that many newly qualified teachers experience a gap between competence acquired during teacher education and competence demands in their professional practice as schoolteachers (Mausethagen \& Smeby, 2011). Hence, from a situated perspective on learning (Wenger, 1998), one can argue that the education is of limited value when it comes to preparing for professional practice. Instead, it is emphasised that the actual professional competence development starts when one is employed. The findings presented in this study, however, contradict this assumption. These findings indicate that perceived theoretical understanding and confidence in their role as a teacher as a prospective schoolteacher is of major importance for subsequent perceptions of professional competence as a schoolteacher. The general teacher education programme does not only provide prospective teachers with theoretical knowledge. The programme consists of practical training as well during 20 to 22 weeks of external placement in primary and lower secondary schools. However, the perceived mastery of practicing teaching as a prospective teacher was not measured in this study. Nevertheless, the findings presented in this study indicate that the general teacher-training programme provides a valuable basis for further competence development as a schoolteacher.

Previous research has identified perceived teacher-specific self-efficacy as an important predictor for pupils' learning outcomes, teachers' effort invested in teaching, job satisfaction, professional commitment, burnout and turnover. The findings presented in this study extend previous research that has primarily focused on either the impact of teacher education programmes or the induction period of newly qualified teachers on teacher efficacy. First, the present study shows that a close relationship exists at every measurement level between different aspects of perceived professional competence, such as teaching skills, theoretical understanding and confidence in the role as a teacher. Second, newly qualified 
teachers' perceived professional competence is highly influenced by the anticipation and confidence in their own professional competence that they possessed as prospective teachers. Third, the perceived professional competence of experienced schoolteachers is highly influenced by their experienced professional competence as prospective teachers and, most important, as newly qualified teachers. These results make the perceptions of prospective and newly qualified teachers of their own professional competence a key feature in understanding further development in the perceptions of their own professional competence, which points to the importance of assisting, guiding and encouraging prospective teachers towards being professional. Accordingly, a practical implication is that the initial teacher education programmes should endeavour to promote teachers' beliefs in their own professional competence and teaching ability—and, thereby, their aspirations for further professional development. With regard to students' competence development, the findings indicate the importance of facilitating the positive experience of professional competence. Furthermore, the findings indicate that facilitating a positive experience of professional competence involves providing students with a solid theoretical foundation, mastery experiences and confidence related to professional practice.

Finally, perceived professional competence at the newly qualified teacher level is a necessity for the perceptions of the prospective teacher level to influence the perceptions of more experienced teachers, which indicates that prospective teachers' perceived professional competence has an impact on their later perceptions as more experienced teachers only as long as they continue to experience mastery of teaching requirements. The practical implications of this finding is to facilitate further mastery experience of the teaching task as newly educated schoolteachers, which again underlines the importance of the provision of appropriate support to newly qualified teachers, collegial support and cooperation. 
The results of this longitudinal study are limited by the low response rate, although the current restricted sample at the prospective and newly qualified levels did not significantly differ on either the mean score or correlation coefficients compared with the original sample. Another limitation of this study is the fact that Norwegian schoolteachers receive substantially lower levels of feedback on and support for their teaching performance than teachers in other member countries of the Organisation for Economic Co-operation and Development (OECD). According to the OECD Teaching and Learning International Survey (TALIS), Norwegian teachers are amongst those who receive the least amount of feedback on their teaching performance from school leaders and colleagues (Vibe, Aamodt, \& Carlsten, 2009): 'Teachers rarely observe each other's teaching, and only participate to a small extent in a professional fellowship to discuss each other's teaching' (p. 28). One might therefore speculate whether their perceived professional competence mostly relies on individual teachers' interpretations of the immediate feedback they receive from their pupils. These results indicate that there is great potential for improvement in Norway when it comes to supporting newly qualified teachers and enhancing teachers' feedback on their teaching performance, both from school leaders and colleagues. It would thus be of interest to investigate whether the relationship between Norwegian teachers' perceived professional competence and what they actually do as teachers in some way differs from teachers in other countries with higher levels of cooperation, feedback and support from school leaders and colleagues. Another interesting topic for further research is the relationship involving the following: (1) perceived professional competence, (2) perceived opportunities for mastery experiences in teaching, (3) the development of the ability to discuss teaching practice as prospective teachers and (4) support and participation in cooperation with colleagues as newly qualified teachers. 


\section{References}

Bandura, A. (1997). Self-efficacy: The exercise of control. New York, NY: W.H. Freeman.

Ben-Perez, M. (2011). Teacher knowledge: What is it? How do we uncover it? What are its implications for schooling? Teaching and Teacher Education 27(1), 3-9. doi:10.1016/j.tate.2010.07.015

Bonis, S. A. (2009). Knowing in nursing: A concept analysis. Journal of Advanced Nursing, 65, 1328-1341. doi:10.1111/j.1365-2648.2008.04951.x

Briggs, S. R., \& Cheek, J. M. (1986). The role of factor analysis in the development and evaluation of personality scales. Journal of Personality, 54, 106-148. doi:10.1111/j.1467-6494.1986.tb00391.x

Canrinus, E. T., Helms-Lorenz, M., Beijaard, Buitink, J., \& Hofman, A. (2012), Self-efficacy, job satisfaction, motivation and commitment: exploring the relationships between indicators of teachers' professional identity. Eur J Psychol Educ. 27, 115-132.

Caprara, G. V., Barbaranelli, C., Steca, P., \& Malone, P. S. (2006). Teachers' self-efficacy beliefs as determinants of job satisfaction and students' academic achievement: A study at the school level. Journal of School Psychology, 44, 473-490. doi:10.1016/j.jsp.2006.09.001

Carr, D. (1993). Questions of competence. British Journal of Educational Studies, 41, 253271. doi:10.1080/00071005.1993.9973965

Caspersen, J., \& Raaen, F. D. (2014). Novice teachers and how they cope. Teachers and Teaching: Theory and Practice, 20, 189-211. doi:10.1080/13540602.2013.848570

Christophersen, K. A., Elstad, E., Turmo, A. \& Solhaug, T. (2015). Teacher education programmes and their contribution to student teacher efficacy in classroom management and pupil engagement. Scandinavian Journal of Educational Research. doi.org/10.1080/00313831.2015.1024162 
Cochran-Smith, M., \& Lytle, S. L. (1999). Relationships of knowledge and practice: Teacher learning in communities. Review of research in education, 24, 249-305.

Day, C., \& Sachs, J. (2004). Professionalism, performativity and empowerment: discourses in the politics, policies and purposes of continuing professional development. International handbook on the continuing professional development of teachers, 3-32.

Day, C., Sammons, P., Stobart, G., Kington, A., \& Gu, Q. (2007). Teachers matter: Connecting lives, work and effectiveness. Maidenhead: Open University Press.

Evans, R. J., \& Donnelly, G. W. (2006). A model to describe the relationship between knowledge, skill, and judgment in nursing practice. Nursing Forum, 41, 150-157. doi:10.1111/j.1744-6198.2006.00053.x

Fang, Z. (1996). A review of research on teacher beliefs and practices. Educational research, $38(1), 47-65$.

Gogol, K., Brunner, M., Goetz, T., Martin, R., Ugen, S., Keller, U., Fischbach, A. \& Preckel, F. (2014). "My Questionnaire is Too Long!” The assessments of motivationalaffective constructs with three-item and single-item measures. Contemporary Educational Psychology, 39(3), 188-205. doi: 10.1016/j.cedpsych.2014.04.002

Gold, Y. (1996). Beginning teacher support. Attrition, mentoring, and induction. In J. Sikula, T. J. Buttery \& E. Guyton (Eds.), Handbook of research on teacher education (2nd ed., pp. 548-594). London: Macmillan.

Grangeat, M., \& Gray, P. (2008). Teaching as a collective work: Analysis, current research and implications for teacher education. Journal of Education for Teaching, 34, $177-$ 189. doi:10.1080/02607470802212306

Guo, Y., Connor, C. M. Yang, Y., Roehrig, A. D., \& Morrison, F. J. (2012). The effects of teacher qualification, teacher self-efficacy, and classroom practices on fifth graders' 
literacy outcomes. The Elementary School Journal, 113(1), 3-24. Doi:

$10.1086 / 665816$

Gustafsson, J.-E. (2003). What do we know about effects of school resources on educational results? Swedish Economic Policy Review, 10, 77-1000.

Hatti, J. A. C. (2008). Visible learning: A synthesis of over 800 meta-analyses relating to achievement. London: Routledge.

Hong, J.-Y. (2012). Why do some beginning teachers leave the school, and others stay? Understanding teacher resilience through psychological lenses. Teachers and Teaching: Theory and Practice, 18, 417-440. doi:10.1080/13540602.2012.696044

Hox, J. J., \& De Leeuw, E. D. (1994). A comparison of nonresponse in mail, telephone, and face-to-face surveys. Quality and Quantity, 28, 329-344. doi:10.1007/BF01097014

Hoy, A. W., \& Spero, R. B. (2005). Changes in teacher efficacy during the early years of teaching: A comparison of four measures. Teaching and Teacher Education, 21, 343356. doi:10.1016/j.tate.2005.01.007

Hu, L.-T., \& Bentler, P. M. (1999). Cutoff criteria for fit indexes in covariance structure analysis: Conventional criteria versus new alternatives. Structural Equation Modeling: A Multidisciplinary Journal, 6, 1-55. doi:10.1080/10705519909540118

Johnston, S. (1994). Experience is the best teacher; or is it? An analysis of the role of experience in learning to teach. Journal of Teacher Education, 45, 199-208. doi:10.1177/0022487194045003006

Joram, E. (2007). Clashing epistemologies: Aspiring teachers', practicing teachers', and professors' beliefs about knowledge and research in education. Teaching and Teacher Education, 23, 123-135. doi:10.1016/j.tate.2006.04.032

Klassen, R. M., \& Chiu, M. M. (2011). The occupational commitment and intention to quit of practicing and pre-service teachers: Influence of self-efficacy, job stress, and teaching 
context. Contemporary Educational Psychology. 36, 114-129.

doi:10.1016/j.cedpsych.2011.01.002

Kline, R. B. (2005). Principles and practice of structural equation modeling (2nd ed.). New York, NY: Guilford Press.

Little, D. (1991). Varieties of social explanation. Colorado: Westview Press.

McCormack, A., \& Thomas, K. (2003). Is survival enough? Induction experiences of beginning teachers within a New South Wales context. Asia-Pacific Journal of Teacher Education, 31, 125-138. doi:10.1080/13598660301610

Pajares, M. F. (1992). Teachers' beliefs and educational research: Cleaning up a messy construct. Review of educational research, 62(3), 307-332.

Orlinsky, D. E., \& Rønnestad, M. H. (2005). How psychotherapists develop: A study of therapeutic work and professional growth. Washington, DC: American Psychological Association.

Richter, D., Kunter, M., Klusmann, U., Lüdtke, O., \& Baumert, J. (2011). Professional development across the teaching career: Teachers' uptake of formal and informal learning opportunities. Teaching and Teacher Education, 27, 116-126. doi:10.1016/j.tate.2010.07.008

Skaalvik, E. M. \& Skaalvik, S. (2007) Dimensions of teacher self-efficacy and relations with strain factors, perceived collective teacher efficacy, and teacher burnout. Journal of Educational Psychology, 99(3), 611-625. doi:10.1037/0022-0663.99.3.611

Smeby, J.-C., \& Mausethagen, S. (2011). Kvalifisering til “velferdsstatens" yrker. Utdanning 2011 - veien til arbeidslivet, Statistiske analyser 124. [Qualifying for the occupations of the welfare state - the path to professional occupational life, Statistical analysis 124] (pp. 149-169). Oslo: Statistisk sentralbyrå. 
Sullivan, W. M., \& Rosin, M. S. (2008). A new agenda for higher education: Shaping a life of the mind for practice. San Francisco: John Wiley \& Sons.

Shulman, L. S. (1987). Knowledge and teaching: Foundations of the new reform. Harvard Educational Review, 57, 1-22.

Tschannen-Moran, M., \& Hoy, A. W. (2001). Teacher efficacy: capturing an elusive construct. Teaching and Teacher Education, 17, 783-805.

Tschannen-Moran, M., \& Hoy, A. W. (2007). The differential antecedents of self-efficacy beliefs of novice and experienced teachers. Teaching and Teacher Education, 23, 944-956. doi:10.1016/j.tate.2006.05.003

Tschannen-Moran, M., \& Johnson, D. (2011). Exploring literacy teachers' self-efficacy beliefs: Potential sources at play. Teaching and Teacher Education, 27, 751 -761, doi: 10.1016/j.tate.2010.12.005

Verloop, N., Van Driel, J., \& Meijer, P. (2001). Teacher knowledge and the knowledge base of teaching. International Journal of Educational Research, 35(5), 441-461. doi:10.1016/S0883-0355(02)00003-4

Vibe, N., Aamodt, P. O., \& Carlsten, T. C. (2009). A vare ungdomsskolelarer i Norge. Resultater fra OECDs internasjonale studie av undervisning og laering (TALIS) [To be a lower secondary schoolteacher in Norway. Results from the OECD's international study of teaching and learning (TALIS)]. Rapport 23/2009. Oslo: NIFU STEP.

Ware, H., \& Kitsantas, A. (2007). Teacher and collective efficacy beliefs as predictors of professional commitment. Journal of Educational Research, 100, 303-310. doi:10.3200/JOER.100.5.303-310

Waters-Adams, S. (2006). The relationship between understanding of the nature of science and practice: The influence of teachers' beliefs about education, teaching and learning. International Journal of Science Education, 28(8), 919-944. 
Wenger, E. (1998). Communities of Practice: Learning, Meaning, and Identity. Cambridge: Cambridge University Press.

Wideen, M., Mayer-Smith, J., \& Moon, B. (1998). A critical analysis of the research on learning to teach: Making the case for an ecological perspective on inquiry. Review of Educational Research, 68, 130-178. doi:10.3102/00346543068002130

Winch, C. (2014) Education and Broad Concepts of Agency. Educational Philosophy and Theory, 46(6), 569-583. doi: 10.1080/00131857.2013.779211

Young, M. F. D. (2008). Bringing knowledge back in: From social constructivism to social realism in the sociology of education. London: Routledge. 


\section{Appendix A. Tables}

Table 1. Input data (correlations), $n$, mean, standard deviation, skewness and kurtosis for the observed variables.

Table 2. Maximum likelihood parameter estimates for model 2.

Table 3. Correlations between the latent variables $(n=110)$.

Table 4. Results of the structural equation models.

\section{Appendix B: Figures}

Figure 1. Theoretical model (model 1) of the relationships involving anticipated professional competence as prospective teachers and perceived professional competence as newly qualified teachers and experienced teachers.

Figure 2. Model 2. Standardised estimates for the structural equation modelling (SEM) analysis of the relationships involving anticipated professional competence as prospective teachers and perceived professional competence as newly qualified teachers and experienced teachers $(n=110)$. 


\section{Appendix A. Tables}

Table 1. Input data (correlations), $n$, mean, standard deviation, skewness and kurtosis for the observed variables.

\begin{tabular}{lllllllllll}
\hline Variables & 1 & 2 & 3 & 4 & 5 & 6 & 7 & 8
\end{tabular}

Anticipated professional competence as prospective teachers

1. How confident do you feel in your role as a schoolteacher?

2. How good is your theoretical understanding? $.378 * * *$

Perceived professional competence as newly qualified schoolteachers

3. How confident do you feel in your role as a schoolteacher?

4. How good is your theoretical understanding? $.379 * * * \quad .228 *$

5. How well have you mastered the methods involved $.394 * * * \quad .330^{* *} \quad .448^{* * *} *$ in practising teaching?

Perceived professional competence as experienced schoolteachers

6. How confident do you feel in your role as a schoolteacher?

7. How good is your theoretical understanding?

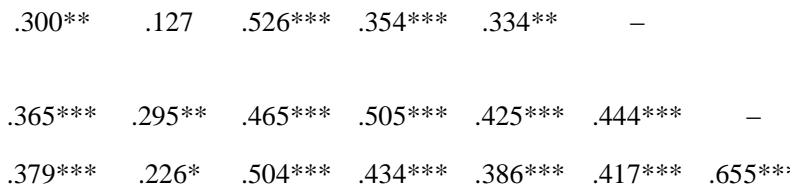
$\begin{array}{llllll}.379 * * * & .226 * \quad .504 * * * & 434 * * * & .386 * * * & .417 * * * & .655 * *\end{array}$

8. How well have you mastered the methods involved in practising teaching?

$N$

Mean

Standard deviation

Skewness

$\begin{array}{llllllll}4.62 & 4.35 & 4.05 & 4.00 & 3.98 & 4.94 & 4.76 & 4.83\end{array}$

$\begin{array}{llllllll}.970 & .759 & .755 & .589 & .658 & .905 & .744 & .731\end{array}$

Kurtosis

$\begin{array}{lllllllll}-.544 & .092 & -.494 & .000 & -.201 & -1.091 & -.543 & -.296\end{array}$

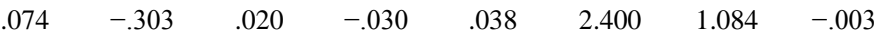

Note. Variables 1, 2, 6-8 are measured on a scale ranging from 1 (absolutely not) to 6 (to a large degree), and variables 3-5 are measured on a scale ranging from 1 (not at all) to 5 (to a very large degree). $* p<.05 . * * p<.01 . * * * p<.001$ level (2-tailed). 
Table 2. Maximum likelihood parameter estimates for model 2.

\begin{tabular}{|c|c|c|c|c|c|c|c|}
\hline Parameter & $\begin{array}{l}\text { Unstd. } \\
\text { estimate }\end{array}$ & $S E$ & $\begin{array}{c}\text { Std. } \\
\text { estimate }\end{array}$ & Parameter & $\begin{array}{l}\text { Unstd. } \\
\text { estimate }\end{array}$ & $S E$ & $\begin{array}{c}\text { Std. } \\
\text { estimate }\end{array}$ \\
\hline & \multicolumn{3}{|c|}{$\underline{\text { Factor loadings }}$} & \multicolumn{4}{|c|}{$\underline{\text { Measurement error (residual variance) }}$} \\
\hline $\begin{array}{l}\text { Anticipated professional competence as } \\
\text { prospective teachers } \rightarrow \mathrm{v} 1\end{array}$ & 1.000 & & .718 & E1 & $.450 * *$ & .140 & $.484 * *$ \\
\hline $\begin{array}{l}\text { Anticipated professional competence as } \\
\text { prospective teachers } \rightarrow \mathrm{v} 2\end{array}$ & .570 & .159 & .522 & E2 & .416 & .070 & .727 \\
\hline $\begin{array}{l}\text { Perceived professional competence as newly } \\
\text { qualified schoolteachers } \rightarrow \text { v3 }\end{array}$ & 1.000 & & .739 & E3 & .255 & .050 & .454 \\
\hline $\begin{array}{l}\text { Perceived professional competence as newly } \\
\text { qualified schoolteachers } \rightarrow \mathrm{v} 4\end{array}$ & .739 & .125 & .698 & E4 & .177 & .032 & .512 \\
\hline $\begin{array}{l}\text { Perceived professional competence as newly } \\
\text { qualified schoolteachers } \rightarrow \text { v5 }\end{array}$ & .837 & .130 & .710 & E5 & .212 & .040 & .496 \\
\hline $\begin{array}{l}\text { Perceived professional competence as } \\
\text { experienced schoolteachers } \rightarrow \mathrm{v} 6\end{array}$ & 1.000 & & .568 & E6 & .550 & .083 & .678 \\
\hline $\begin{array}{l}\text { Perceived professional competence as } \\
\text { experienced schoolteachers } \rightarrow \mathrm{v} 7\end{array}$ & 1.171 & .212 & .810 & E7 & .188 & .043 & .344 \\
\hline \multirow[t]{2}{*}{$\begin{array}{l}\text { Perceived professional competence as } \\
\text { experienced schoolteachers } \rightarrow \mathrm{v} 8\end{array}$} & 1.116 & .205 & .786 & E8 & .202 & .041 & 383 \\
\hline & \multicolumn{3}{|c|}{$\underline{\text { Direct effects }}$} & \multicolumn{4}{|c|}{ Disturbance variances } \\
\hline $\begin{array}{l}\text { Anticipated professional competence as } \\
\text { prospective teachers } \rightarrow \text { Perceived professional } \\
\text { competence as newly qualified schoolteachers }\end{array}$ & $.583 * *$ & .172 & .729 & D1 & $.144^{*}$ & .061 & $.468 * *$ \\
\hline $\begin{array}{l}\text { Perceived professional competence as newly } \\
\text { qualified schoolteachers } \rightarrow \text { Perceived } \\
\text { professional competence as experienced } \\
\text { schoolteachers }\end{array}$ & .759 & .163 & .823 & D2 & $.084^{*}$ & .037 & $.322 *$ \\
\hline
\end{tabular}

$\underline{\text { Mediated effect }}$

Anticipated professional competence as $.443 * * \quad .147 \quad .600$ prospective teachers $\rightarrow$ Perceived professional competence as newly qualified schoolteachers $\rightarrow$ Perceived professional competence as experienced schoolteachers

Note. $\mathrm{CFI}=$ comparative fit index; $\mathrm{CI}=$ confidence interval; $d f=$ degrees of freedom; RMSEA = root mean square error of approximation; $S E=$ standard error; $\mathrm{SRMR}=$ standardised root mean square residual; Std. estimate $=$ standardised estimate; Unstd. estimate $=$ unstandardised estimate.

$n=110$. Fit indices: chi-square $=20.071, d f=18$, and $p=.329 ; \mathrm{CFI}=.992 ; \mathrm{RMSEA}=.032(90 \% \mathrm{CI}, 0.000-0.093) ; \mathrm{SRMR}=.040$. $* p<.05 . * * p<.01 . p<.001$ for all other estimates. 
Table 3. Correlations between the latent variables $(n=110)$.

\begin{tabular}{lccc}
\hline & $\begin{array}{c}\text { Anticipated professional } \\
\text { competence as prospective } \\
\text { teachers }\end{array}$ & $\begin{array}{c}\text { Perceived professional } \\
\text { competence as newly qualified } \\
\text { schoolteachers }\end{array}$ & $\begin{array}{c}\text { Perceived professional } \\
\text { competence as experienced } \\
\text { schoolteachers }\end{array}$ \\
\hline $\begin{array}{l}\text { Anticipated professional } \\
\text { competence as prospective } \\
\text { teachers }\end{array}$ & - & \\
$\begin{array}{l}\text { Perceived professional } \\
\text { competence as newly qualified } \\
\text { schoolteachers }\end{array}$ & $.693 * * *$ \\
$\begin{array}{l}\text { Perceived professional } \\
\text { competence as experienced } \\
\text { schoolteachers }\end{array}$ & $.639 * * *$ & $.807 * * *$ \\
\end{tabular}

Note. $\mathrm{CFI}=$ comparative fit index; $\mathrm{CI}$ = confidence interval; $d f=$ degrees of freedom; RMSEA = root mean square error of approximation; SRMR $=$ standardised root mean square residual.

Fit indices: chi-square $=19.539, d f=17$, and $p=.299 ; \mathrm{CFI}=.990 ; \mathrm{RMSEA}=.036$ (90\% CI, 0.000-0.097); and SRMR $=.040$.

$* * * p<.001$.

Table 4. Results of the structural equation models.

\begin{tabular}{|c|c|c|c|c|}
\hline & $\begin{array}{l}\text { Unst. } \\
\text { estimate }\end{array}$ & $S E$ & Std. estimate & $p$ \\
\hline \multicolumn{5}{|l|}{ Model 1} \\
\hline $\begin{array}{l}\text { Anticipated professional competence as prospective teachers } \rightarrow \text { Perceived } \\
\text { professional competence as newly qualified schoolteachers }\end{array}$ & .554 & .173 & .693 & .000 \\
\hline $\begin{array}{l}\text { Anticipated professional competence as prospective teachers } \rightarrow \text { Perceived } \\
\text { professional competence as experienced schoolteachers }\end{array}$ & .111 & .147 & .152 & .439 \\
\hline $\begin{array}{l}\text { Perceived professional competence as newly qualified schoolteachers } \rightarrow \text { Perceived } \\
\text { professional competence as experienced schoolteachers }\end{array}$ & .640 & .208 & .701 & .002 \\
\hline \multicolumn{5}{|c|}{ Fit indices: chi-square $=19.539, d f=17$, and $p=.299 ;$ CFI $=.990 ;$ RMSEA $=.037(90 \%$ CI, 0.000-0.097); SRMR $=.040$} \\
\hline \multicolumn{5}{|l|}{ Model 2} \\
\hline $\begin{array}{l}\text { Anticipated professional competence as prospective teachers } \rightarrow \text { Perceived } \\
\text { professional competence as newly qualified schoolteachers }\end{array}$ & .583 & .172 & .729 & .000 \\
\hline $\begin{array}{l}\text { Perceived professional competence as newly qualified schoolteachers } \rightarrow \text { Perceived } \\
\text { professional competence as experienced schoolteachers }\end{array}$ & .759 & .163 & .823 & .000 \\
\hline \multicolumn{5}{|c|}{ Fit indices: chi-square $=20.071, d f=18$, and $p=.329 ; \mathrm{CFI}=.992 ; \mathrm{RMSEA}=.032(90 \% \mathrm{CI}, 0.000-0.093) ; \mathrm{SRMR}=.040$} \\
\hline
\end{tabular}

Note. $n=110$. CFI = comparative fit index; CI, confidence interval; $d f=$ degrees of freedom; RMSEA, root mean square error of approximation; $S E$, standard error; SRMR, standardised root mean square residual; Std. estimate, standardised estimate; Unst. estimate, unstandardised estimate. 


\section{Appendix B: Figures}

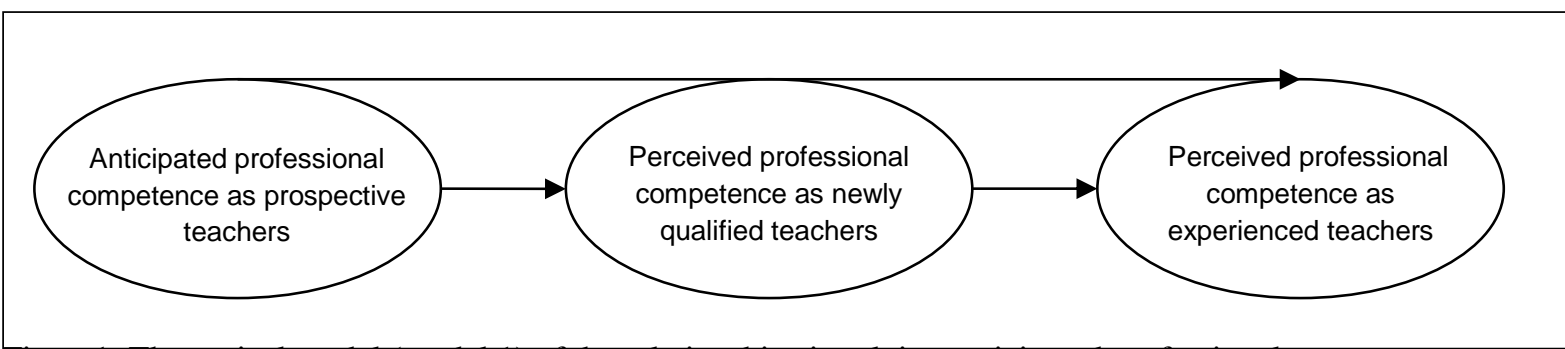

Figurel. Theoretical model (model 1) of the relationships involving anticipated professional competence as prospective teachers and perceived professional competence as newly qualified teachers and experienced teachers.

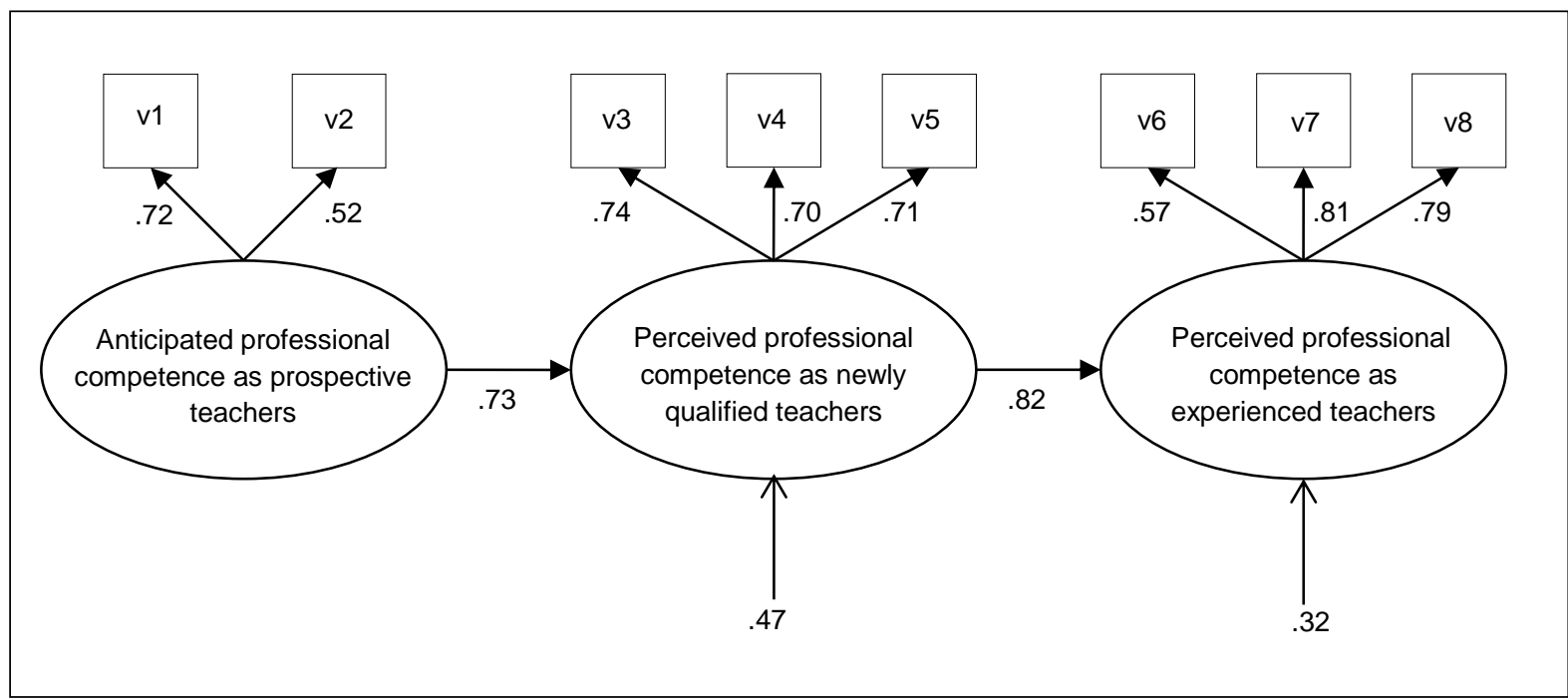

Figure 2. Model 2. Standardised estimates for the structural equation modelling (SEM) analysis of the relationships involving anticipated professional competence as prospective teachers and perceived professional competence as newly qualified teachers and experienced teachers $(n=110)$. 


\section{Highlights:}

- Theoretical understanding, practical skills and professional confidence correlates

- Perceived professional competence influence succeeding perceptions of competence

- Theoretical understanding is important for teachers' competence development

- Supporting teacher efficacy is important for both prospective and novice teachers 